\title{
STEROID COMPOUNDS FROM Gynura pseudochina (Lour) DC
}

\section{SENYAWA STEROID DARI Gynura pseudochina (Lour) DC}

\author{
Ferlinahayati $^{1 *}$, Roby Pahala J Gultom ${ }^{1}$, Herlina ${ }^{2}$, Eliza ${ }^{1}$ \\ ${ }^{1}$ Department of Chemistry, Faculty of Mathematics and Natural Sciences, \\ Sriwijaya University, Palembang, Indonesia \\ ${ }^{2}$ Department of Pharmacy, Faculty of Mathematics and Natural Sciences, \\ Sriwijaya University, Palembang, Indonesia \\ *email: etihayati74@yahoo.com
}

Received March 2, 2017; Accepted May 10, 2017; Available online May 30, 2017

\begin{abstract}
Daun dewa (Gynura pseudochina Lour DC) is a one of popular traditional medicine to treat various diseases. This research was conducted to isolate chemical compounds from daun dewa leaves using various chromatographic techniques. A steroid mixture namely $\beta$-sitosterol (1a) and stigmasterol (1) were isolated for the first time from the methanol extract of daun dewa. The structures were determined base on spectral evidence including IR, NMR 1D and NMR 2D.
\end{abstract}

Keywords: Gynura pseudochina, $\beta$-sitosterol, stigmasterol.

\begin{abstract}
ABSTRAK
Daun dewa (Gynura pseudochina Lour DC) merupakan salah satu tumbuhan tradisional yang dimanfaatkan untuk mengobati berbagai penyakit. Penelitian ini bertujuan untuk mengisolasi senyawa kimia dari daun tumbuhan daun dewa. Suatu campuran steroid yaitu $\beta$-sitosterol (1a) dan stigmasterol (1b) telah diisolasi untuk pertama kalinya dari ekstrak metanol Gynura pseudochina (Lour) DC. Struktur kedua senyawa ditetapkan berdasarkan data-data spektroskopi yaitu IR, NMR 1D dan 2D.
\end{abstract}

Kata kunci: Gynura pseudochina, $\beta$-sitosterol, stigmasterol

\section{INTRODUCTION}

Gynura pseudochina (Lour) DC which locally name in Indonesia known as daun dewa is belongs to the Asteraceae family. The plant is a well-known traditional herbs in South East Asia, and it is widely used to treat eruptive fever, ulcer, detoxification, bleeding, rash, diabetes melitus, herves and cancer (Lemmens \& Bunyapraphatsara, 2003; Hew, Ko \& Gam, 2013). This genus contains some bioactive compounds such as pyrrolizidine and pyrazine alkaloids (Siriwatanametanon \& Heinrich, 2011; Shimizu, et al, 2010), flavonoid, chlorogenic acid (Wan, Yu, Zhou, Tian \& Cao, 2011) and terpenoid (Shimizu, et al, 2011). Some extract of this genus have been reported as antioxidant (Wan, et al., 2011), antihyperglycemia, antihypertension (Wu et al., 2011), antiangiogenic (Seow, et al., 2011), $\mathrm{NF}_{-\mathrm{K}} \mathrm{B}$ inhibitory (Siriwatanametanon \& Heinrich, 2011) and antidiabetic (Hassan, Yam, Ahmad, \& Yusof, 2010; Algarii, et al., 2013).

Some phenolic compound such as quercetin 3-rutinoside, 3,5-dicaffeoylquinic acid, 4,5-di-caffeoylquinic acid, and 5monocaffeoylquinic acid have been isolated from G. Pseudocina (Siriwatanametanon \& Heinrich, 2011). These pure compounds showed significant inhibitory activities against $\alpha$-glucosidase and considerable inhibitory effect against PTP1B which correlated for treatment type-2 diabetic (Chen, 2014). As a part of our research on phytochemistry from $G$. pseudochina, two steroid compound namely $\beta$-sitosterol (1a) and stigmasterol (1b) have been isolated from methanol extract of this plant. The steroid was isolated as a mixture compound. The isolation and the structure elucidation of a mixture steroid will be reported.

\section{MATERIAL AND METHODS}

Materials

Daun dewa ( $G$. pseudochina) were collected from Bandung, West Java, Indonesia. 


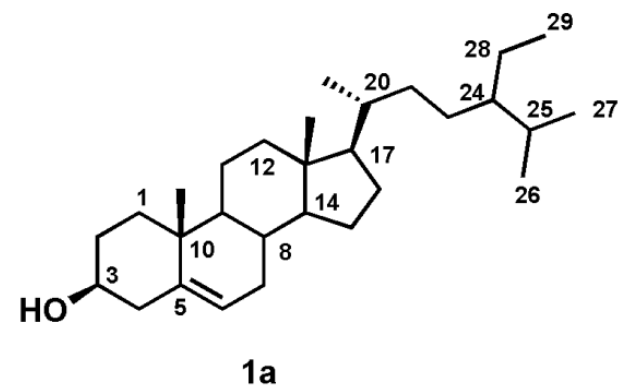

$1 a$

The plant species was identified at Herbarium Bogoriense, Cibinong, Indonesia. Vacuum liquid chromatography (VLC) was carried out using Merck silica gel $60 \mathrm{GF}_{254}$, while column chromatography was carried out using Merck silica gel 60 (70-230 mesh). Silica gel plates (Merck Kieselgel $60 \mathrm{GF}_{254}, 0.25 \mathrm{~mm}$ ) were used for TLC analysis. Visualization of TLC plates was carried out under UV at $254 \mathrm{~nm}$, as well as by spraying the plates with cerium sulfate $1,5 \%$ in sulfuric acid $2 \mathrm{~N}$. The organic solvents were used in this research should be pro analysis (p.a) and distilled, i.e., chloroform, methanol, $n$-hexane, ethyl acetate and acetone.

\section{Instrumentation}

Melting points were determined using Fisher John Apparatus. IR spectra were determined with a Perkin-Elmer FTIR Spectrum One spectrometer using $\mathrm{KBr}$ pellets. ${ }^{1} \mathrm{H}$ and ${ }^{13} \mathrm{C}$ NMR spectra were recorded with Agilent DD2 spectrometer, operating at 500 $\left({ }^{1} \mathrm{H}\right)$ and $125\left({ }^{13} \mathrm{C}\right) \mathrm{MHz}$, using residual and deuterated solvent peaks as reference standards.

\section{Procedure}

The dried powder of G. pseudochina (1 $\mathrm{kg}$ ) was extracted with methanol at room temperature for 24 hours $(3 \mathrm{~L})$, the process was repeated for three times. The methanol extracts were evaporated under reduce pressure to give a dark-green residue $(35.71 \mathrm{~g})$. A portion of methanol extract was fractionated on a silica gel vacuum liquid chromatography (VLC) using stepwise gradients of $n$-hexane with increasing amount of ethyl acetate (10:0 to 0:10) and ethyl acetate-methanol $(9: 1)$ to afford ten major fraction A-J $(2.14 ; 0.39 ; 0.08 ; 0.46 ; 0.62$; $0.53 ; 0.78 ; 1.04 ; 1.76$ and 5.05 g respectively). A greenish solid $(0.39 \mathrm{~g})$ contained in the fraction B. This fraction was dissolved in $n$ hexane as little as possible to produce a greenish white solid $(260 \mathrm{mg})$. It was further

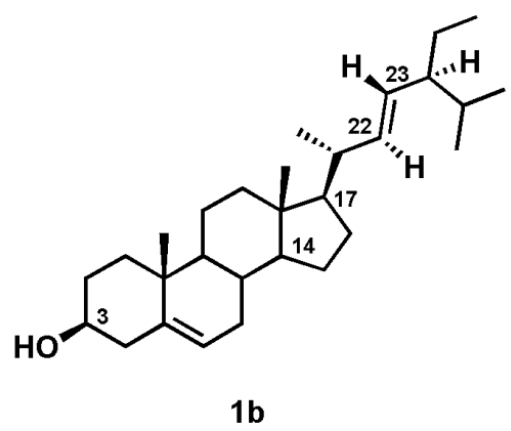

separated by column chromatography (silica gel, eluted with $n$-hexane-ethyl acetate, 98:2 to $85: 15)$ to give compound $\mathbf{1}(165 \mathrm{mg})$.

\section{RESULTS AND DISCUSSION}

A solid white compound $(165 \mathrm{mg})$ with m.p 123-125 ${ }^{\circ} \mathrm{C}$ was isolated from the methanol extract of $G$. pseudochina after separated by several chromatographic techniques. The isolated compound consistently showed one spot on TLC in the various eluent system. The IR spectra showed a strong absorption at 2933 and $2869 \mathrm{~cm}^{-1}$ were derived from stretching vibration of $\mathrm{C}-\mathrm{H}$ aliphatic, whereas absorption at 1463 and $1384 \mathrm{~cm}^{-1}$ were $\mathrm{C}-\mathrm{H}$ bending vibration. The absorption at the wave number of $3430 \mathrm{~cm}^{-1}$ was identified as a hydroxyl group $(\mathrm{OH})$ which was supported by $\mathrm{C}-\mathrm{O}$ vibration at $1053 \mathrm{~cm}^{-1}$. The presence of absorption at 1642 $\mathrm{cm}^{-1}$ indicated that compound has an unsaturated bond $(\mathrm{C}=\mathrm{C})$. These are a typical absorption of steroid or terpenoid.

NMR spectra $\left({ }^{1} \mathrm{H}-\mathrm{NMR},{ }^{13} \mathrm{C}-\mathrm{NMR}\right.$ and HMQC) analysis of isolated compound was indicated to be a mixture of two steroid compounds. It's based on the presence of twelve methyl group, four of them are singlet methyl. Typically, a steroid only has six methyl groups including two of them are singlet methyl. Based on the signal intensity of these four methyl singlet on ${ }^{13} \mathrm{C}-\mathrm{NMR}$ spectra $\left(\delta_{\mathrm{C}} 12.0,12.1,12.2\right.$ and $\left.12.4 \mathrm{ppm}\right)$ then the composition of the steroid mixture was 2:1. This assumption was supported by comparison signal intensity between methine vinylic signal at $\delta_{\mathrm{C}} 129.4 \& 138.4$ (for minor compound) with methine vinylic signal at $\delta_{\mathrm{C}}$ $121.8 \mathrm{ppm}$ (for two steroid mixture). By combining data from the ${ }^{1} \mathrm{H}-\mathrm{NMR},{ }^{13} \mathrm{C}-\mathrm{NMR}$, HMQC and observed the signal intensity of carbon, the signal of each steroid could be determined. 
Table 1. NMR data of $\beta$-sitosterol (1a) and stigmasterol (1b) in $\mathrm{CDCl}_{3}$

\begin{tabular}{|c|c|c|c|c|c|}
\hline \multirow[b]{2}{*}{ No } & \multicolumn{2}{|r|}{$1 \mathbf{a}$} & \multicolumn{2}{|r|}{ 1b } & \multirow{2}{*}{$\begin{array}{l}1 \mathrm{a} \& 1 \mathrm{~b} \\
\text { HMBC }\end{array}$} \\
\hline & $\begin{array}{c}\delta_{\mathrm{C}} \\
\mathbf{p p m}\end{array}$ & $\delta_{\mathrm{H}}($ multiplicity, $J \mathbf{H z})$ & $\delta_{\mathrm{C}} \mathbf{p p m}$ & $\delta_{\mathrm{H}}($ multiplicity, $J \mathbf{H z})$ & \\
\hline \multirow[t]{2}{*}{1} & 37.4 & a. $1.84(1 \mathrm{H}, m) \mathrm{H}-\mathrm{eq}$ & 37.4 & a. $1.84(1 \mathrm{H}, m) \mathrm{H}-\mathrm{eq}$ & C5,C3,C10,C2, C19 \\
\hline & & b. $1.07(1 \mathrm{H}, m) \mathrm{H}-\mathrm{ax}$ & & b. $1.07(1 \mathrm{H}, m) \mathrm{H}-\mathrm{ax}$ & C9, C2, C19 \\
\hline \multirow[t]{2}{*}{2} & 31.8 & a. $1.83(1 \mathrm{H}, m) \mathrm{H}-\mathrm{eq}$ & 31.8 & a. $1.83(1 \mathrm{H}, m) \mathrm{H}-\mathrm{eq}$ & $\mathrm{C} 3, \mathrm{C} 4, \mathrm{C} 10$ \\
\hline & & b. $1.49(1 \mathrm{H}, m) \mathrm{H}-\mathrm{ax}$ & & b. $1.49(1 \mathrm{H}, m) \mathrm{H}-\mathrm{ax}$ & $\mathrm{C} 3, \mathrm{C} 4$ \\
\hline 3 & 71.9 & $3.52(1 \mathrm{H}, m) \mathrm{H}-\mathrm{ax}$ & 71.9 & $3.52(1 \mathrm{H}, m) \mathrm{H}-\mathrm{ax}$ & - \\
\hline 4 & 42.4 & $2.25(2 \mathrm{H}, m)$ & 42.4 & $2.25(2 \mathrm{H}, m)$ & $\mathrm{C} 5, \mathrm{C} 6, \mathrm{C} 3, \mathrm{C} 10, \mathrm{C} 2$ \\
\hline 5 & 140.9 & - & 140.9 & - & - \\
\hline 6 & 121.8 & a. $5.34(1 \mathrm{H}, b r d, 4.8)$ & 121.8 & a. $5.34(1 \mathrm{H}$, br $d, 4.8)$ & $\mathrm{C} 4, \mathrm{C} 10, \mathrm{C} 7, \mathrm{C} 8$ \\
\hline \multirow[t]{2}{*}{7} & 32.0 & a. $1.97(1 \mathrm{H}, m)$ & 32.0 & a. $1.97(1 \mathrm{H}, m)$ & $\mathrm{C} 5, \mathrm{C} 6, \mathrm{C} 9, \mathrm{C} 8$ \\
\hline & & b. $1.51(1 \mathrm{H}, m)$ & & b. $1.51(1 \mathrm{H}, m)$ & $\mathrm{C} 5, \mathrm{C} 6, \mathrm{C} 14, \mathrm{C} 8$ \\
\hline 8 & 32.0 & $1.44(1 \mathrm{H}, m)$ & 32.0 & $1.44(1 \mathrm{H}, m)$ & C9, C7, C14 \\
\hline 9 & 50.3 & $0.92(1 \mathrm{H}, m)$ & 50.3 & $0.92(1 \mathrm{H}, m)$ & $\mathrm{C} 8, \mathrm{C} 19, \mathrm{C} 12$ \\
\hline 10 & 36.6 & - & 36.6 & - & - \\
\hline \multirow[t]{2}{*}{11} & 21.3 & a. $1.50(1 \mathrm{H}, m)$ & 21.3 & a. $1.50(1 \mathrm{H}, m)$ & C9, C13, C12, C8 \\
\hline & & b. $1.43(1 \mathrm{H}, m)$ & & b. $1.43(1 \mathrm{H}, m)$ & $\mathrm{C} 9, \mathrm{C} 12, \mathrm{C} 8$ \\
\hline \multirow[t]{2}{*}{12} & 39.9 & a. $2.00(1 \mathrm{H}, m)$ & 39.8 & a. $2.00(1 \mathrm{H}, m)$ & $\mathrm{C} 14, \mathrm{C} 9, \mathrm{C} 11$ \\
\hline & & b. $1.16(1 \mathrm{H}, m)$ & & b. $1.16(1 \mathrm{H}, m)$ & $\mathrm{C} 19, \mathrm{C} 9, \mathrm{C} 18$ \\
\hline 13 & 42.5 & - & 42.3 & - & - \\
\hline 14 & 56.9 & $0.99(1 \mathrm{H}, m)$ & 57.0 & $0.99(1 \mathrm{H}, m)$ & $\mathrm{C} 13, \mathrm{C} 15, \mathrm{C} 8$ \\
\hline \multirow[t]{2}{*}{15} & 24.4 & a. $1.56(1 \mathrm{H}, m)$ & 24.5 & a. $1.56(1 \mathrm{H}, m)$ & $\mathrm{C} 14, \mathrm{C} 13, \mathrm{C} 16$ \\
\hline & & b. $1.05(1 \mathrm{H}, m)$ & & b. $1.05(1 \mathrm{H}, m)$ & $\mathrm{C} 14, \mathrm{C} 16$ \\
\hline \multirow[t]{2}{*}{16} & 28.4 & a. $1.84(1 \mathrm{H}, m)$ & 29.0 & a. $1.70(1 \mathrm{H}, m)$ & $\mathrm{C} 17, \mathrm{C} 13$ \\
\hline & & b. $1.26(1 \mathrm{H}, m)$ & & b. $1.26(1 \mathrm{H}, m)$ & $\mathrm{C} 14, \mathrm{C} 20$ \\
\hline 17 & 56.2 & $1.12(1 \mathrm{H}, m)$ & 56.1 & $1.12(1 \mathrm{H}, m)$ & $\mathrm{C} 13, \mathrm{C} 12, \mathrm{C} 20$ \\
\hline 18 & 12.0 & $0.67(3 \mathrm{H}, s)$ & 12.2 & $0.69(3 \mathrm{H}, s)$ & $\mathrm{C} 12^{*}, \mathrm{C} 13^{*}, \mathrm{C} 14, \mathrm{C} 17$ \\
\hline 19 & 19.5 & $1.00(3 \mathrm{H}, s)$ & 19.5 & $1.00(3 \mathrm{H}, s)$ & $\mathrm{C} 5, \mathrm{C} 9, \mathrm{C} 1, \mathrm{C} 10$ \\
\hline 20 & 36.3 & $1.35(1 \mathrm{H}, m)$ & 40.6 & $2.04(1 \mathrm{H}, m)$ & $\begin{array}{l}\mathrm{C} 16 *, \mathrm{C} 17, \mathrm{C} 21, \\
\mathrm{C} 22 * *, \mathrm{C} 23 * *\end{array}$ \\
\hline 21 & 18.9 & $0.91(3 \mathrm{H}, d, 6.4)$ & 21.4 & $1.01(3 \mathrm{H}, d)$ & $\mathrm{C} 17, \mathrm{C} 20, \mathrm{C} 22$ \\
\hline \multirow[t]{2}{*}{22} & 34.1 & a. $1.32(1 \mathrm{H}, m)$ & 138.4 & $\begin{array}{l}5.15(1 \mathrm{H}, d d, 8.7 \& \\
15.2)\end{array}$ & $\begin{array}{l}\mathrm{C} 17, \mathrm{C} 20, \mathrm{C} 21, \\
\mathrm{C} 23 * *, \mathrm{C} 24 * *\end{array}$ \\
\hline & & b. $1.01(1 \mathrm{H}, m)$ & & - & $\mathrm{C} 17, \mathrm{C} 23$ \\
\hline 23 & 26.2 & $1.16(2 \mathrm{H}, m)$ & 129.4 & $\begin{array}{l}5.01(1 \mathrm{H}, d d, 8.7 \& \\
15.2)\end{array}$ & $\begin{array}{l}\mathrm{C} 22, \mathrm{C} 24, \mathrm{C} 28, \\
\mathrm{C} 20^{* *}, \mathrm{C} 25^{* *}, \mathrm{C} 28^{* *}\end{array}$ \\
\hline 24 & 46.0 & $0.92(1 \mathrm{H}, m)$ & 51.4 & $1.52(1 \mathrm{H}, m)$ & $\begin{array}{l}\mathrm{C} 25, \mathrm{C} 23, \mathrm{C} 28, \mathrm{C} 29 \\
\mathrm{C} 26^{* *}, \mathrm{C} 27^{* *}\end{array}$ \\
\hline 25 & 29.3 & $1.66(1 \mathrm{H}, m)$ & 32.1 & $1.44(1 \mathrm{H}, m)$ & $\begin{array}{l}\text { C24, C23, C28 *, C26, } \\
\text { C27 }\end{array}$ \\
\hline 26 & 20.0 & $0.83(3 \mathrm{H}, d, 6.7)$ & 21.2 & $0.84(3 \mathrm{H}, d)$ & $\mathrm{C} 24, \mathrm{C} 25, \mathrm{C} 27$ \\
\hline 27 & 19.2 & $0.80(3 \mathrm{H}, d, 6.4)$ & 19.1 & $0.80(3 \mathrm{H}, d)$ & $\mathrm{C} 24, \mathrm{C} 25^{* *}, \mathrm{C} 26$ \\
\hline \multirow[t]{2}{*}{28} & 23.2 & $1.25(2 \mathrm{H}, m)$ & 25.6 & a. $1.41(1 \mathrm{H}, m)$ & $\mathrm{C} 24, \mathrm{C} 25, \mathrm{C} 23, \mathrm{C} 29$ \\
\hline & & - & & b. $1.16(1 \mathrm{H}, m)$ & $\mathrm{C} 23^{* *}, \mathrm{C} 24 * *$ \\
\hline 29 & 12.1 & $0.84(3 \mathrm{H}, t, 6.3)$ & 12.4 & $0.79(3 \mathrm{H}, t, 8.8)$ & $\mathrm{C} 24, \mathrm{C} 28$ \\
\hline
\end{tabular}

The ${ }^{13} \mathrm{C}-\mathrm{NMR}$ data (Table 1) of major compound (1a) disclosed the presence of 29 carbon signals that indicated of stigmastane steroid. The ${ }^{13} \mathrm{C}-\mathrm{NMR}$ spectra, supported with the information from heteronuclear multiple quantum coherence (HMQC) spectra revealed signal due to 6 signals for methyl carbon $\left(\delta_{\mathrm{C}}\right.$ $12.0 ; 12.1 ; 18.9 ; 19.2 ; 19.5$ and $20.0 \mathrm{ppm}), 11$ signals for methylene carbon $\left(\delta_{\mathrm{C}} 21.3 ; 23.2\right.$; $24.4 ; 26.2 ; 28.4 ; 31.8 ; 32.0 ; 34.1 ; 37.4 ; 39.9$ 
and $42.4 \mathrm{ppm}), 7$ signals for methine carbon $\left(\delta_{\mathrm{C}} 29.3 ; 32.0 ; 36.3 ; 46.0 ; 50.3 ; 56.2 ; 56.9\right.$ $\mathrm{ppm})$, one signal for oxymethine carbon $\left(\delta_{\mathrm{C}}\right.$ $71.9 \mathrm{ppm}$ ), one signal for methine olefinic carbon $\left(\delta_{\mathrm{C}} 121.8 \mathrm{ppm}\right)$ and the rest were signals for quartenary carbon $\left(\delta_{\mathrm{C}} 36.6\right.$ and $42.5 \mathrm{ppm})$ including quartenary olefinic carbon $\left(\delta_{\mathrm{C}} 140.9 \mathrm{ppm}\right)$. Therefore, the major compound was stigmastane steroid containing a hydroxyl group and one double bond.

The ${ }^{1} \mathrm{H}-\mathrm{NMR}$ spectra (Table 1) showed an olefinic proton at $\delta_{\mathrm{H}} 5.34 \mathrm{ppm}(1 \mathrm{H}, b r d$, $J=4.8 \mathrm{~Hz}$ ) and an oxymethine proton at $\delta_{\mathrm{H}}$ $3.52 \mathrm{ppm}(1 \mathrm{H}, m)$. These signals are characteristic for stigmast-5-en-3-ol steroid. Furthermore, the two of six methyl signal that characteristic for stigmastane steroid appeared as singlet at $\delta_{\mathrm{H}} 0.67 \mathrm{ppm}(3 \mathrm{H}, s)$ and 1.00 ppm $(3 \mathrm{H}, s)$ to be located at $\mathrm{C}-18$ and $\mathrm{C}-19$ respectively. Another three metil signals were displayed as doublet at $\delta_{\mathrm{H}} 0.91 \mathrm{ppm}(3 \mathrm{H}, d, J$ $=6.4 \mathrm{~Hz}) ; 0.83 \mathrm{ppm}(3 \mathrm{H}, d, J=6.7 \mathrm{~Hz})$ and $0.80 \mathrm{ppm}(3 \mathrm{H}, d, J=6.4 \mathrm{~Hz})$ to be located at C-21, C-26, C-27 respectively. The rest methyl signal is for C-29, displayed as triplet at $\delta_{\mathrm{H}} 0.84 \mathrm{ppm}(3 \mathrm{H}, t, J=6.3 \mathrm{~Hz})$. The long range correlation in the heteronuclear multiple-bond correlation (HMBC) spectrum between a proton signal at $\delta_{\mathrm{H}} 1.00 \mathrm{ppm}$ with the quartenary $\mathrm{sp}^{2}$ carbon signal at $\delta_{\mathrm{C}} 140.9$ ppm, secured the position of this singlet methyl signal at C-19. The correlation in the correlation spectroscopy (COSY) spectra between two of doublet methyl signal at $\delta_{\mathrm{H}}$ 0.83 and $0.80 \mathrm{ppm}$ with the methine signal at $\delta_{\mathrm{H}} 1.66 \mathrm{ppm}$, confirmed the position of these methyl signals at C-26 and C-27 respectively (Figure 1a).

Stereochemistry of hydroxyl group at C-3 was determined base on the nuclear overhouser effect spectroscopy (NOESY) spectra. The NOESY spectra showed correlation between methyl signal at $\delta_{\mathrm{H}} 1.00$ ppm (H-19) with a methylene signal at $\delta_{\mathrm{H}}$ $1.49 \mathrm{ppm}(\mathrm{H}-2)$, secured the orientation of this methylene signal as an axial, so that another methylene signal at $\delta_{\mathrm{H}} 1.83 \mathrm{ppm}(\mathrm{H}-2)$ is equatorial. Furthermore, the correlation between oxymethine signal at $\delta_{\mathrm{H}} 3.52 \mathrm{ppm}$ $(\mathrm{H}-3)$ with methylene signal at $\delta_{\mathrm{H}} 1.83 \mathrm{ppm}$ $(\mathrm{H}-2)$, confirmed the oxymethine signal as an axial orientation so that the hydroxyl group is equatorial ( $3 \beta$ ). Correlation between H-18 with $\mathrm{H}-20$ as well as correlations between $\mathrm{H}-$ 17 with $\mathrm{H}-21$ was secured the side chain on the axial position.

These NOESY correlation are equal to compound 1b (Figure 2) Base on this evidence, the major compound (1a) was assigned as stigmasta-5-en-3 $\beta$-ol or $\beta$ sitosterol. Comparison NMR data with those reported by Greca, Monaco \& Previtera, 1990 showed high similarity. Other HMBC correlations for supported the structure of 1a are shown in Table $\mathbf{1}$ while COSY correlation is shown in Figure 1.
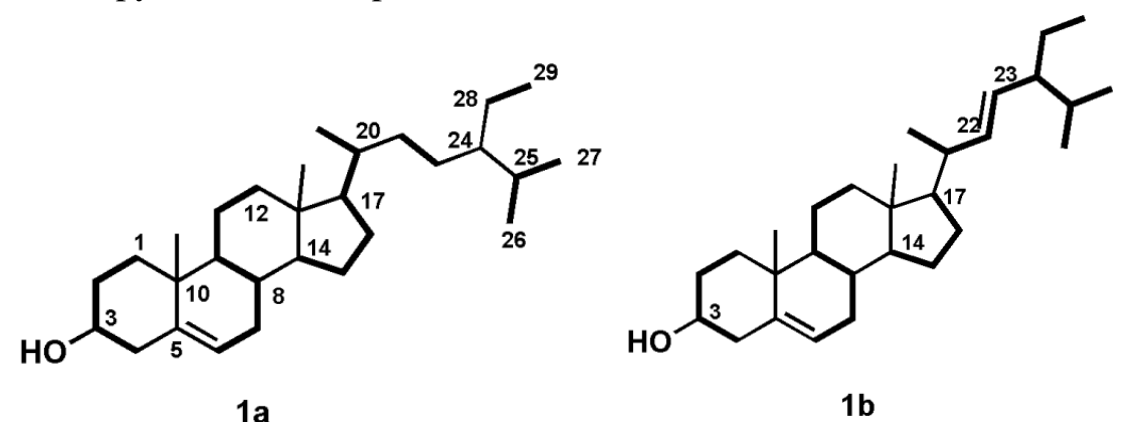

Figure 1. COSY correlation of compound $\mathbf{1 a}$ and $\mathbf{1 b}$

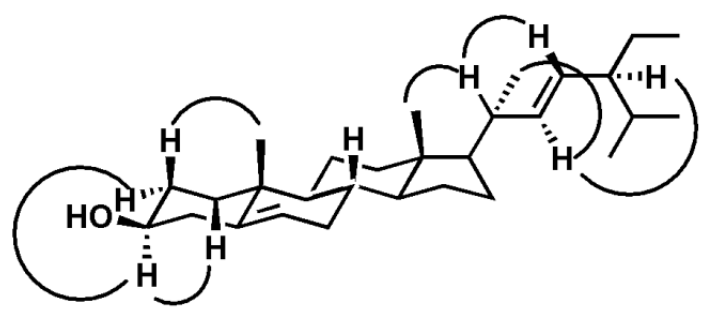

Figure 2. Some NOESY correlation of compound $\mathbf{1 b}$ 
The ${ }^{13} \mathrm{C}-\mathrm{NMR}$ data (Table 1) of minor compound (1) disclosed the presence of 29 carbon signals that indicated of stigmastane steroid. These signals were including 6 signals for methyl carbon $\left(\delta_{\mathrm{C}} 12.2 ; 12.4 ; 19.5 ; 19.1\right.$; 21.2 and $21.4 \mathrm{ppm}), 9$ signals for methylene carbon $\left(\delta_{\mathrm{C}} 21.3 ; 24.5 ; 25.6 ; 29.0 ; 31.8 ; 32.0\right.$; $37.4 ; 39.9$ and $42.4 \mathrm{ppm}), 7$ signals for methine carbon $\left(\delta_{\mathrm{C}} 32.0 ; 32.140 .6 ; 51.4\right.$; $50.3 ; 56.1 ; 57.0 \mathrm{ppm})$, one signal for oxymethine $\left(\delta_{\mathrm{C}} 71.9 \mathrm{ppm}\right)$, three signals for methine olefinic carbon $\left(\delta_{\mathrm{C}} 121.8 ; 129.4\right.$ and $138.4 \mathrm{ppm})$ and the rest were signals for quartenary carbon $\left(\delta_{\mathrm{C}} 36.6\right.$ and $\left.42.3 \mathrm{ppm}\right)$ including quartenary carbon of olefinic $\left(\delta_{\mathrm{C}}\right.$ $140.9 \mathrm{ppm})$. Some of these carbon signals overlapped with the major compound, especially in the tetracyclic skeleton. The significant difference with the major compound is in the amount of carbon olefinic. The minor compound has four olefinic carbons which were identified as two unsaturated bonds. These data indicated that two steroid compounds have the same functional group on tetracyclic skeleton but they are different in the side chain.

The ${ }^{1} \mathrm{H}-\mathrm{NMR}$ spectra of compound $\mathbf{1 b}$ (Table 1) was similar to compound 1a on tetracyclic skeleton. However, compound $\mathbf{1 b}$ has two additional trans-olefinic protons at $\delta_{\mathrm{H}}$ $5.15(1 \mathrm{H}, d d, 8.7 \& 15.2 \mathrm{~Hz})$ and $5.01 \mathrm{ppm}$ $(1 \mathrm{H}, d d, 8.7 \& 15.2 \mathrm{~Hz})$. These signal were indicated the side chain have a double bond at $\mathrm{C}-22$ and $\mathrm{C}-23$ respectively. The HMBC correlation from olefinic proton $\mathrm{H}-22\left(\delta_{\mathrm{H}}\right.$ 5.15) to $\mathrm{C}-17\left(\delta_{\mathrm{C}} 56.1\right), \mathrm{C}-20\left(\delta_{\mathrm{C}} 40.6\right)$ and methyl carbon $\mathrm{C}-21\left(\delta_{\mathrm{C}} 21.4\right)$, as well as HMBC correlation from olefinic proton $\mathrm{H}-23$ $\left(\delta_{\mathrm{H}} 5.01\right)$ to $\mathrm{C}-24\left(\delta_{\mathrm{C}} 51.4\right)$ and methylene carbon $\mathrm{C}-28\left(\delta_{\mathrm{C}} 25.6\right)$ were supported the assigment of double bond at C-22 and C-23. These proton signal at C-20 and C-24 were shifted to downfield in $\mathbf{1 b}$ compared to $\mathbf{1 a}$, owing to interaction with double bond. The NOESY spectra showed correlation between methine signal at $\delta_{\mathrm{H}} 2.04 \mathrm{ppm}(\mathrm{H}-20)$ with a methyl signal at $\delta_{\mathrm{H}} 0.69 \mathrm{ppm}(\mathrm{H}-18)$ and an olefinic proton signal at $5.01 \mathrm{ppm}(\mathrm{H}-23)$, indicated they were in the same side (axial orientation). While, correlation between an olefinic proton signal at $\delta_{\mathrm{H}} 5.15 \mathrm{ppm}(\mathrm{H}-22)$ with methine signal at $\delta_{\mathrm{H}} 1.12(\mathrm{H}-17)$ and $1.52(\mathrm{H}-24) \mathrm{ppm}$ also indicated they were in the same side (equatorial orientation) but an opposite side to H-20 (Figure 2). These correlation were indicated that both of olefinic proton signal as trans position as well as the coupling constan analysis $(J=15,2 \mathrm{~Hz})$. Thus, the minor compound (1) was assigned as stigmasta-5,22-dien-3 $\beta$-ol or stigmasterol. Other HMBC correlations are shown in Table 1, while COSY and NOESY correlation are shown in Figure 1 and Figure 2 respectively.

Both of the isolated compound are known compound. It has been reported from G. Bicolor (Zhuo, et al., 2008), G. Divaricata (Chen, et al., 2003) and G. Segetum (Seow, et al., 2011), but according to our knowledge is the first reported from $G$. pseudochina. $\beta$ sitosterol and stigmasterol are common phytosterols in plant. They can reduce cholesterol level and as antiinflammation (Huang, Zhong, Chen, Ye \& Chen, 2007). Dietary of such phytosterol in food are associated with a cancer reduction with directly inhibit tumor with apoptosis mechanism (Bradford \& Award, 2007).

\section{CONCLUSION}

The steroid mixture namely $\beta$-sitosterol and stigmasterol have been isolated for the first time from the methanol extract of $G$. pseudochina. The structures of these mixture were determined by spectroscopic data including IR, NMR 1D and 2D.

\section{ACKNOWLEDGEMENTS}

We are grateful to DP2M Dikti for research funding through Hibah Fundamental 2013-2014. We thank to the Herbarium Bogoriense, Cibinong, Indonesia, for identification of the plant specimen and to Prof. Dr. Yana Maolana Syah from Institut Teknologi Bandung for NMR measurements.

\section{REFERENCES}

Algarii, K., Meng, K.Y., Atangwho, I.J., Asmawi, M.Z., Sadikun, A .... \& Ismail, N. (2013). Hypoglycemic and anti-hyperglycemic study of Gynura procumbens leaf extracts. Asian Pacific Journal of Tropical Biomedicine, 3(5), 358-366. doi : 10.1016/S22211691(13)60077-5.

Bradford, P.G. \& Awad, A.B. (2007). Phytosterol as anticancer compounds. Molecular Nutrition and Food 
Research, 51, 161-170. doi: 10.1002/mnfr.200600164

Chen, S.C., Hong, L.L., Chang, C.Y., Chen, C.J., Hsu, M.H. .... Kuo, S.C. (2003). Antiproliferative constituents from Gynura divaricata subsp. formosana. Chinese Pharmaceutical Journal, 55(2), 109-119.

Chen, J., Mangelinckx, S., Ma, L., Wang, Z., Li, W. \& Kimpe, N.D. (2014). Caffeoylquinic acid derivatives isolated from the aerial parts of Gynura divaricata and their yeast $\alpha$-glucosidase and PTP1B inhibitory activity. Fitoterapia, $\quad 99, \quad 1-6$. doi :10.1016/j.fitote.2014.08.015

Greca, M.D., Monaco, P. \& Previtera, R. (1990). Stigmasterols from Typha latifolia. Journal of Natural Product, 53(6), 1430-1435.

Hassan, Z., Yam, M.F., Ahmad, M. \& Yusof, A.P.M.(2010). Antidiabetic properties and mechanism of action of Gynura procumbens water extract in Streptozocin-Induced diabetic rats. Molecules, 15 9008-9023.doi : 10.3390/molecules15129008

Hew C-S, Khoo B-Y. \& Gam L-H. (2013). The Anti-cancer property of proteins extracted from Gynura procumbens (Lour.) Merr. PLoS ONE 8(7): e68524. doi:10.1371/journal.pone.0068524.

Huang, L., Zhong, T., Chen, T., Ye, Z. \& Chen, G. (2007). Identification of $\beta$ sitosterol, stigmasterol and ergosterin in A. roxburghii using supercritical fluid extraction followed by liquid chromatography/atmospheric pressure chemical ionization ion trap mass spectrometry. Rapid Communication in Mass Spectrometry, 21, 3024-3032. doi : $10.1002 / \mathrm{rcm} .3181$

Lemmens, R.H.M.J. \& Bunyapraphatsara, N. (2003). Plant Resource Of South East Asia : Medical and Poisomous Plants. Backhuys Publishers, Leiden, 312p.
Seow, L.J., Beh, H.K., Majid, A.M.S., Murugaiyah, V., Ismail, N. \& Asmawi, M.Z.(2011). Anti-angiogenic activity of Gynura segetum leaf extract and its fraction. Journal of Ethnopharmacology, 134(2), 221-227. doi10.1016/j.jep.2010.12.007

Shimizu, Y., Imayoshi, Y., Kato, M., Maeda, K., Iwabuchi, H. \& Shimomura, K., (2011). New eudesmane-type sesquiterpenoids and other volatile constituens from the root of Gynura bicolor DC. Flavour and Fragrans Journal, 26, 55-64. doi: $10.1002 / f f j .2016$.

Siriwatanametanon, N. \& Heinrich, M., (2011).The Thai medicinal plant Gynura pseudochina var hispida: Chemical composition and in vitro NFкВ inhibitory Activity. Natural Product Communications, 6(5), 627-630.

Wan, C., Yu, Y., Zhou, S., Liu, W., Tian, S. \& Cao, S. (2011). Antioxidant activity and free radical-scavenging capacity of Gynura divaricata leaf extracts at different temperatures, Pharmacognosy Magazine, 7(25), 40-45. doi: 10.4103/0973-1296.75900.

Wan, C., Yu, Y., Zhou, S.,Tian, S. \& Cao, S. (2011).Isolation and identification of phenolic compounds from Gynura divaricata leaves, Pharmacognosy Magazine, 7(26), 101-108. doi:10.4103/0973-1296.80666

Wu, T., Zhou, X., Deng, Y., Jing, Q., Li, M. \& Yuan, L.(2011). In Vitro studies of Gynura divaricata (L.) DC extracts as inhibitors of key enzymes relevant for type 2 diabetes and hypertension. Journal of Ethnopharmacology, 136(2), 305-308. doi.10.1016/j.jep.2011.04.059.

Zhuo, M., Lu, H., Ren, B., Li, W., Zhao, Z. \& Zhang, H. (2008). Chemical constituents of Gynura bicolor, Zhongcaoyao, 39(1), 30-32. 